\title{
The Endothelium and Hemodialysis
}

\author{
Hernán Trimarchi \\ Hospital Británico de Buenos Aires, \\ Argentina
}

\section{Introduction}

The endothelium is a functional barrier composed of a single layer of endothelial cells between the vessel wall and circulating blood. The human vascular bed has a combined surface area of $1000 \mathrm{~m}^{2}$ and contains $10^{13}$ endothelial cells. The endothelium is the largest endocrine organ, with also important paracrine and autocrine functions (Perry \& Pearson, 1989). Endothelial cells play important roles in haemostasis, vasoactivity, cellular proliferation, immunological reactions and inflammatory events. Therefore, endothelial dysfunction can lead to vasoconstriction, local ischemic phenomena and hypertension, thrombus formation and plaque growth and rupture, vascular proliferation and remodeling, and immunologic inflammation processes. Risk factors for endothelial dysfunction include old age, hypertension, diabetes mellitus, hypercholesterolemia, tobacco, menopause, male gender and obesity (Müller \& Griesmacher, 2000; Raitakari \& Celermajer, 2000).

Cardiovascular disease is the leading cause of mortality in dialysis patients. In large crosssectional studies of dialysis patients, traditional cardiovascular risk factors such as hypertension and hypercholesterolemia have been found to have low predictive power, while markers of inflammation and malnutrition are highly correlated with cardiovascular mortality. However, the pathophysiology of the disease process that links uremia, inflammation, and malnutrition with increased cardiovascular complications is not well understood. In uremia, endothelial dysfunction derives from a systemic altered milieu that is partially aggravated by the dialysis treatment itself. From water quality to the type of membrane employed, many artificial factors intervene that trigger inflammatory processes culminating with endothelial damage, smooth muscle cell hyperplasia, fibrosis and vascular calcification.

The underlying vascular disease consists mainly of two types, arteriosclerosis and atherosclerosis. Arteriosclerosis is mainly characterized by premature arterial aging with loss of elastic fibers and increased stiffness. Atherosclerosis is characterized by intima-media thickening, plaque formation and luminal narrowing. Both processes may interact simultaneously, possibly via diverse mechanisms, as endothelial dysfunction, shear stress, and elastic fiber fragmentation (Fishbein \& Fishbein, 2009; Guérin et al., 2008; London \& Drüeke, 1997).

Endothelial dysfunction is a well-documented early phenomenon in atherosclerosis that precedes structural changes and clinical manifestations, particularly in dialysis patients (Frick \& Weidinger, 2007). Decreased endothelial function is thought to primarily reflect a decreased bioavailability of nitric oxide, a critical endothelium-derived vasoactive factor 
with vasodilatory and anti-atherosclerotic properties (Tatematsu et al., 2007). Although endothelial dysfunction is common as renal function declines, the exact causes are not known. The effects of various uremic toxins on endothelial dysfunction and cardiovascular outcome are being studied. There is also growing evidence that asymmetric dimethylarginine, an endogenous inhibitor of nitic oxide-synthase, is involved in mediating endothelial damage and dysfunction (Kielstein \& Zoccali, 2005), is primarily cleared by the kidney, is elevated in chronic kidney disease and is associated with poor prognosis in dialysis patients (Stenvinkel et al., 2008).

Increased oxidative stress is an outstanding culprit in the process of increased atherogenesis and cardiovascular morbidity and mortality found in the dialysis population. Vascular and endothelial complications accelerate as renal function is progressively decreased in the predialysis population, which is potentiated in chronic kidney disease Stage 5. Increasing number of biomarkers are constantly emerging as potential culprits in this process of accelerated atherogenesis and thrombosis in haemodialyzed subjects (Himmelfarb et al., 2002).

Oxidative stress, endothelial dysfunction, inflammation, protein-energy wasting, sympathetic activation, haemostatic disturbances, endocrine disturbances, uremic retained toxins, vascular calcification and ossification, infections, anemia and its therapy, and certain haemodialysis components are amongst the main uremia-related biochemical risk factors in patients on dialysis (Stenvinkel et al., 2008). Increased levels of oxidative stress markers are present in the plasma of chronic kidney patients, which indicates that uremia is a prooxidant state (Himmelfarb et al., 2002). Oxidative stress seems to occur early in kidney disease evolution because oxidative markers have been documented at least as early as stage 3 (Oberg et al., 2004). Moreover, dialysis treatment seems ineffective in the correction of oxidative stress and may sometimes trigger oxidant processes, although recent data may show the opposite (Pupim et al., 2004; McGregor et al., 2003).

There exists an activated inflammatory response in $30-50 \%$ of patients with end-stage renal disease (Zimmermann et al., 1999), even before dialysis is started: C-Reactive protein levels, one of the non-specific but highly sensitive markers usually employed to assess inflammation, may also be raised by persistent infections; comorbidities as chronic heart failure or chronic angina; accumulation of oxidative stress by-products; and proinflammatory cytokines retained in uremia (Stenvinkel, 2001a). Chronic inflammation, mediated by pro-inflammatory cytokines and acute-phase reactants, may contribute to accelerated atherosclerosis (Stenvinkel, 2001a). Normal endothelial function is crucial for cardiovascular homeostasis. Endothelial dysfunction results in lipid accumulation at the vessel wall, smooth muscle proliferation, and vasospasm and is associated with inflammation in advanced chronic kidney disease patients (Stenvinkel, 2001b). Finally, endothelial dysfunction and inflammation is associated with oxidative stress, leading to atherosclerosis and tissue hypoxia (Handelman et al., 2001).

Vascular calcification and ossification, present in $30 \%$ to $70 \%$ of chronic kidney patients, is virtually always associated with dialysis due to both arterial intima and media disturbances, plaque formation, hypertension and atherogenesis (Sigrist et al., 2006; Schwarz et al., 2000), and is related to arterial dysfunction because it alters nitric oxide-dependent vasodilatation and increases pulse-wave velocity in dialysis patients (Raggi et al., 2007). Calcium, hyperphosphatemia and hyperparathyroidism are risk markers of vascular calcification, and vitamin $\mathrm{D}$ deficiency is associated with increased mortality and cardiovascular disease 
(Block et al., 2005). An antagonist of vascular calcification, fetuin-A, is low in dilaysis patients and is associated with increased cardiovascular mortality (Ix et al., 2007).

Emerging evidence suggests that aberrant DNA methylation may play a deleterious role in atherosclerosis and endothelial dysfunction (Dong et al., 2002). DNA methylation changes occur during atherogenesis and may contribute to lesion development. The homocysteine precursor S-adenosylmethionine is a competitive inhibitor of S-adenosylmethionine methyltransferases and is increased in haemodilaysis patients. This phenomenon leads to unbalanced methylation in the setting of hyperhomocysteinemia. In vascular disease patients increased homocysteine and S-adenosylmethionine concentrations are associated with DNA hypomethylation (Castro et al., 2003; Valli et al., 2008). In this regard, the presence of inflammation may partly contribute to an association between homocysteine levels, endothelial dysfunction and cardiovascular outcome in dialysis subjects, resulting in part in aberrant DNA methylation (Stenvinkel et al., 2008; Teitell \& Richardson, 2003).

Finally, endothelial cells modify their function in response to changes in the extracellular concentration of sodium and potassium, constantly present in dialysis patients. The control of local tissue perfusion that the endothelium exerts may play an important in vascular tone and the development of hypertension and atherosclerosis (Oberleithner et al., 2010).

\section{The endothelium in normal conditions}

The endothelium is a functional and anatomic barrier composed of a single layer of endothelial cells between the vessel wall and blood. The human vascular bed contains $10^{13}$ endothelial cells, constituting our largest endocrine organ (Perry \& Pearson, 1989). Endothelial cells play important roles in vascular tone, haemostasis, cellular proliferation, immunological processes and inflammatory events. The normal endothelium regulates vascular smooth muscle tone; exerts anticoagulant, fibrinolytic and antithrombotic actions; is involved in lipid, lipoprotein and eicosanoid metabolism; is a selective barrier for the normal trafficking of molecules from the interstitial tissue to the blood stream and viceversa, and contributes to vascular growth, leukocyte adhesion, and immunological processes.

\subsection{Regulation of vascular tone}

The endothelium releases a wide variety of substances both vasodilators and vasoconstrictors. Relaxing factors consist primarily of nitric oxide, prostacyclin, hyperpolarizing factor, bradykinin, and adrenomedullin. Constricting factors include mainly endothelin-1, thromboxane A2, prostaglandin $\mathrm{H} 2$, angiotensin II and free radicals. Amongst the relaxing molecules, nitric oxide constitutes the basis of endothelium-related vasorelaxation. Nitric oxide is synthesized by nitric oxide synthase from the N-terminal of L-arginine guanidine, is an unstable molecule with a half-life of a couple of seconds. There are three forms of nitric oxide: type I or neuronal, type II or inducible, and type III or endothelial, which is specific to the endothelium. Nitric oxide synthase is stimulated by nicotinamide dinucleotide (phosphate) (NADPH) and 5,6,7,8-tetrahydrobiopterin and inhibited by powerful oxidants as superoxide anions and hydrogen peroxide (Verma \& Anderson, 2002). Excess inducible nitric oxide caused by many inflammatory cytokines such as tumor necrosis factor-alpha, interleukin- 1 or -6 results in an exaggerated vasodilatation, whilst interleukins-4, $-8,-10$ and transforming growth factor-beta decrease nitric oxide expression (Webb \& Vallance, 1997). Endothelial cells release nitric oxide into the 
surrounding smooth muscle cells of the vascular wall in a paracrine manner, causing vasodilatation and inhibiting their growth, and into the vascular lumen, impeding local platelet and leukocyte adhesion (Vanhoutte et al., 1997). One of the most important causes of endothelial nitric oxide release is shear stress. The physical stimulus of a faster or a pulsatile blood flow in the arterial wall leads to vasodilatation. Endogenous substances that stimulate nitric oxide release are catecholamines, vasopressin, bradykinin, histamine, serotonin, ADP and thrombin. The interaction between the normal endothelium and platelets is crucial for vascular tone stability and haemostasis.

Amongst the vasoconstrictors produced by endothelial cells, endothelin plays an important role. Endothelins are 21-aminoacid peptides classified as 1 to 3, with a half-life of approximately 2 minutes and are derived from proendothelin in a reaction catalyzed by endothelin converting enzyme. Endothelin-1 is specific to the endothelium, is released paracrinally towards the vascular wall where it exerts its powerful vasoconstrictor effect on the smooth muscle cells (Yanashigawa et al., 1988; Clozel \& Fischli, 1989). The most potent regulator of endothelin-1 production and release is blood flow. An increase in blood flow results in vasodilatation due to the activation of shear stress receptors in the endothelial cells, which increases nitric oxide synthesis and release and reduces endothelin-1 production (Webb \& Vallance, 1997). Other endothelin-1 stimulants include hypoxia, angiotensin-II, insulin, thrombin, low-density lipoproteins, vasopressin, transforming growth factor-beta and plasminogen activator inhibitor-1 (Webb \& Vallance, 1997). The vasoconstrictor and proliferative action of endothelin-1 on vascular smooth muscle cells is mediated by A receptors, mainly in large vessels. When B receptors are activated, they also mediate vasoconstriction in small arteries and in the low-pressure venous bed. Endothelial B receptors, however, participate in other effects: clearance of circulating endothelin-1, inhibition of endothelin-1 synthesis, and paradoxically can also stimulate endothelial nitric oxide synthase activity, leading to vasodilatation and antiproliferative effects. (Webb \& Vallance, 1997).

\subsection{Regulation of haemostasis}

The endothelial layer affects platelet function, plasma coagulation, and fibrinolysis. The physiologic role of the endothelium is to provide an antithrombotic surface; when endothelial damage occurs, the endothelium is converted into a prothrombotic layer (Cines et al., 1998). Factors with procoagulant effects on endothelial cells include reactive oxygen species, oxidized lipids, shear stress and slow blood flow, inflammation, age and certain hormones (Müller \& Griesmacher, 2000). Moreover, the endothelium itself produces, according to the circumstances, both anticoagulant and procoagulant factors. The former action is mediated mainly by nitric oxide, prostacyclin, tissue plasminogen activator, thrombomodulin and antithrombin III, while the latter is starred by platelet activating factor, tissue factor, endothelin, thrombin, plasminogen activator inhibitor- 1 and factor VIII. Coagulation itself results not only in thrombosis, but also stimulates inflammation and cellular growth. In fact, thrombin is involved in coagulation, anticoagulation, proinflammatory and anti-inflammatory processes, cell adhesion and proliferation. Indeed, there is a strong association between inflammation and coagulation at the cellular level (Esmon, 1999). The physiology of haemostasis, inflammation and thrombosis, involves adhesion of leukocytes and platelets suspended in flowing blood to the vessel wall. Recent findings underscore the importance of blood flow and of exposed vessel wall structures in 
these processes. Platelet-dependent haemostasis at injured vessel walls is more extensive at higher shear. However, leukocyte adhesion to endothelium increase at slow shear (Kuijper et al., 1996; Mackay \& Imhof, 1993). Multiple receptor-ligand interactions are usually needed for attachment. Endothelial secreted selectins are first released, which interact with platelets for their adhesion and for platelet and endothelial synthesis of integrins. This process results in the recruitment of leukocytes through the action of intracellular adhesion molecules, vascular cell adhesion molecules and platelet endothelial cell adhesion molecules (Mulvihill et al., 2002). The next step is the migration of leukocytes to the subintimal space and later to the medial layer, where they interact with smooth muscle cells, fibroblasts and macrophages. This platelet-bridged action for leukocyte entrance into the vascular wall is independent of blood flow speed and shear (Mackay \& Imhof, 1993). Finally, endothelial cells affect fibrinolysis synthesizing fibrinolyic factors and fibrinolysis inhibiting factors: Urokinase, tissue plasminogen activator, and plasminogen activator inhibitor. Briefly, tissue plasminogen activator is released from endothelial cells and cleaves plasminogen to form plasmin, a potent fibrinolytic substance in a fine physiological balance with plasminogen activator inhibitor-1, a protein also released from endothelial cells that antagonizes tissue plasminogen activator. The levels of both molecules are increased as a result of excess stimulation of endothelial cells by thrombin or as a result of endothelial dysfunction (Huber, 2001; Kuijper et al., 1996).

\section{The endothelium and chronic kidney disease}

Patients with end-stage renal disease are at high risk of developing cardiovascular disease and decreasing their life survival. Renal insufficiency may be part and/or cause of a systemic subclinical atherothrombotic process (Stam et al., 2003). As mentioned before, arteriosclerosis can contribute to atherosclerosis and vice versa, possibly through endothelial dysfunction, biomechanical and blood flow stress to endothelial cells, and elastic fragmentation (Guérin et al., 2008). Both processes can ultimately lead to vascular calcification and ossification, clinically assessed as an increase in arterial stiffness and hypertension (McEniery et al., 2009). Accelerated atherogenesis at any stage of chronic kidney disease may be due to the interplay of traditional and nontraditional risk factors, such as asymmetric dimethylarginine, homocysteine, advanced glycation end products, endothelial lipidosis, oxidative stress processes and inflammatory molecules (Goligorsky, 2007). Therefore, it is correct to consider endothelial dysfunction as a heterogenous syndrome, which can be focused either as a local or a systemic condition, as in chronic kidney disease; with subclinical or clinical manifestations; being reversible or irreversible according to its severity; and with many related etiologic mechanisms, as already mentioned (Goligorsky, 2007). In chronic kidney disease, endothelial dysfunction is characterized by increased plasma concentrations of endothelium-derived molecules, an imbalance between circulating endothelial cell and bone-marrow endothelial progenitor cells, or reduced endothelium-dependent vasodilatation (van Guldener et al., 1997; Rabelink et al., 2010). As renal function deteriorates, an atherogenic milieu generates due to the accumulation of uremic toxins with direct impact on the endothelium and the vessel wall, contributing to oxidative stress and enhancing a subclinical inflammatory state. In chronic kidney disease, these initial steps in endothelial dysfunction may perpetuate if not identified at the early subclinical stages, leading to atherogenesis (Ross, 1999). Decreased endothelial function is thought to primarily reflect a decreased bioavailability of nitric oxide, a molecule with 
vasodilatory and antiatherosclerotic properties (Tatematsu et al., 2007). Asymmetric dimethylarginine, an endogenous inhibitor of nitric oxide synthase, is involved in atherogenesis, is primarily cleared by the kidney and is elevated in kidney disease (Kielstein \& Zoccali, 2005). Dimethylarginine is considered as an independent predictor of endothelial dysfunction and poor outcome in dialysis patients (Zoccali et al., 2001).

Albuminuria is another predictor of increased cardiovascular risk (de Zeeuw, 2007). Albuminuria is also associated with other cardiovascular risk factors, such as abnormalities in fibrinolysis (Annavekar \& Pfeffer, 2004), inflammation (Festa et al., 2000), and dyslipidemia (Tonelli \& Pfeffer, 2007). Although the nature of the links between albuminuria and vascular disease may partly be due to endothelial dysfunction, persistent low-grade inflammation also plays a role. Indeed, inflammation is associated with both endothelial dysfunction (Stenvinkel, 2001b) and albuminuria (Festa et al., 2000). Noteworthy, albeit frequently present, proteinuria seldom is considered as a cause of inflammation, protein-energy wasting and endothelial dysfunction in hemodialysis.

Albuminuria is strongly associated with increased levels of pentraxin-3, an inflammatory mediator produced by a variety of tissues and cells, mainly endothelial cells, macrophages and adipocytes, in response to proinflammatory signals (Abderrahim-Ferkoune et al., 2003; Mantovani et al., 2006). Pentraxin-3 is elevated in dialysis subjects (Boehme et al., 2007) and is being considered as a new mortality risk factor in dialysis patients (Tong et al., 2007). This suggests that it may have an additional role in the atherogenic process to common inflammatory mediators (Stenvinkel et al., 2008). Because of its extrahepatic synthesis, pentraxin-3 levels are believed to be an independent indicator of disease activity directly produced at sites of inflammation and linked to endothelial dysfunction.

Detached circulating endothelial cells may serve as potential markers of endothelial damage in kidney disease (Koc et al., 2005). These circulating endothelial cells include endothelial progenitor cells, which are bone marrow-derived, and inflammatory endothelial cells, which are thought to be detached from the vessel walls and enter the circulation as a result of vascular injury. Normally, in response to ischemic insult and cytokine stimulation, endothelial progenitor cells are mobilized from the bone marrow to act as repair cells in response to the endothelial injury. In kidney disease there exists an impaired migratory activity and/or decreased numbers (Herbrig et al., 2004) of these cells, which may have a role in neovascularization of ischemic tissue and the progression of atherosclerosis and cardiovascular disease (Hill et al., 2003). Low levels of circulating endothelial progenitor cells predicted the occurrence of cardiovascular events and death. An imbalance between the expression of circulating endothelial cells (reflecting inflammatory endothelial damage) and endothelial progenitor cells (reflecting endothelial repair capacity) seems to exist in chronic kidney disease (Stenvinkel et al., 2008). This imbalance may contribute to the pathogenesis and progression of the atherosclerosis.

In agreement with Stenvinkel et al., until the results of new studies regarding this issue become available, endothelial dysfunction should be considered a cardiovascular marker and not an etiological factor in kidney patients, intimately related to oxidative stress and inflammation (Stenvinkel et al., 2008).

\subsection{The endothelium and oxidative stress}

Under normal conditions, reactive oxygen species (which include various compounds such as superoxide anions, hydrogen peroxide, and hydroxyl radical) are produced in 
mammalian cells during energy production in mitochondria by reducing oxygen during aerobic respiration (Pieczenik \& Neustadt, 2007). In addition, a variety of enzymatic and nonenzymatic sources of reactive oxygen species exist in vascular vessels as well as different tissues, among which can be included nicotinamide dinucleotide (phosphate) (NAD $(\mathrm{P}) \mathrm{H}$ oxidase enzyme complex, xanthine oxidase, lipoxygenases, and cyclooxygenases (Portaluppi et al., 2004). An uncoupling of nitric oxide synthase, owing to the reduction of its cofactor, BH4, can also contribute to oxygen metabolites (Andrew \& Mayer, 1999). Reactive oxygen species levels are maintained at a normal range by scavenging through various antioxidant enzyme activities such as superoxide dismutase, catalase, glutathione peroxidase, and other components such as reduced glutathione, transition metal ions, and ascorbic acid. (Blokhina et al., 2003). Reactive oxygen species are part of the organism's unspecified initial defense system. However, excessive reactive oxygen species levels can produce cellular damage by interacting with biomolecules; this imbalance, which the cellular components cannot bear long, is called oxidative stress.

As mentioned, oxidative stress takes place when the production of oxidants exceeds local antioxidant capacity, resulting in the oxidation of proteins, lipids, carbohydrates, and DNA. Briefly, oxidative stress biomarkers can be classified as derived from lipids (malondialdehyde, lipid hydroperoxides, oxidized low-density lipoprotein, advanced lipoxidation end products), arachidonic acid derivatives (F2 isoprostanes), carbohydrates (reactive aldehydes, advanced glycosylation end products), amino acids (cysteine/cystine, homocysteine/homocystine), proteins (carbonyl formation, advanced oxidation protein products) and DNA (8 hydroxy 2' deoxyguanine) (Himmelfarb et al., 2002). Oxidative stress can occur via four different chemical pathways: Oxygen reactive species can lead to the production of advanced glycosilation end-products (carbonyl stress); to the inhibition of nitric oxide synthase (nitrosative stress); to the production of hydrogen peroxide and chlorine hydroxide (chlorinated stress); and to the generation of hydroxide species with the intervention of iron molecules (classical oxidative stress). Definitively, chlorinated stress is the most important pathway implicated in renal failure (Massy et al., 2003; Himmelfarb et al., 2001).

Uremia is a prooxidant state. Lipid peroxidation, oxidative modification of proteins and carbohydrates and certain uremic toxins themselves have been implicated in endothelial dysfunction in chronic renal disease (Himmelfarb et al., 2002; Linden et al., 2008; Oberg et al., 2004; Trimarchi et al., 2003). Moreover, numerous defects in antioxidant systems lead to a decrease in the depuration of reactive oxygen species. Oxidative stress appears to start early in chronic kidney disease (Oberg et al., 2004), but total antioxidant capacity has been observed to be excelled only in end-stage renal failure, suggesting that reactive oxygen species production start overcoming their clearance at the beginning of the decline in renal function. Finally, dialysis treatment may have contradictory effects on it, depending on the quality, modality, and duration of the procedure itself (Pupim et al., 2004; Hand et al., 1998; McGregor et al., 2003).

Although priming of polymorphonuclear leukocytes is a prominent feature in chronic kidney disease (Hörl, 2002), and myeloperoxidase is involved in chlorinated stress, the exact role of inflammation as a trigger of oxidative stress remains poorly defined in renal disease. As suggested, longitudinal studies of patients with mild chronic kidney disease are needed to resolve the issue of which is the initial culprit: inflammation or oxidative stress (Stenvinkel et al., 2008). 
Oxidative stress in the kidney and vascular tissues can elevate arterial pressure via several mechanisms. Reactive oxygen species react with and inactivate nitric oxide; it also perturbs its production production by depleting the nitric oxide synthase cofactor tetrahydrobiopterin; and it contributes to accumulation of asymmetrical dimethylarginines, which in turn curtails nitric oxide production. Reduced bioavailability of nitric oxide, as a resultant of endothelial dysfunction, enhances the development and maintenance of hypertension by augmenting systemic vascular resistance, by increasing adrenergic tone, volume expansion and vascular smooth muscle cell proliferation, matrix accumulation and vascular remodeling, which are inhibited by nitric oxide and and promoted by free radicals (Wilcox, 2005). Another mechanism by which oxidative stress can cause hypertension and atherogenesis in renal failure is via nonenzymatic oxidation of arachidonic acid and formation of isoprostanes, which display vasoconstrictor, proinflammatory and antinatriuretic activity (Vaziri \& Rodríguez-Iturbe, 2006; Schnackenberg, 2002). Finally, oxidative stress enhances the production of angiotensin II, which leads to increased blood pressure by promoting sodium retention and renal vasoconstriction (Navar et al., 2002). Moreover, oxidative stress increases production of endothelin-1 and the cytosolic concentration of calcium, thereby increasing vascular smooth muscle tone, systemic vascular resistance, arterial pressure and accumulation of matrix proteins (Kahler et al., 2001; Touyz, 2005).

\subsection{The endothelium and inflammation}

In chronic kidney disease, a state of persistent low-grade inflammation is commonly observed. Chronic inflammation is characterized by the persistent effect of a causative stimulus, which leads to destruction of cells and tissues and has deleterious effects to the body. In chronic kidney disease, especially in stage 5, the systemic concentrations of both pro- and anti-inflammatory cytokines are several-fold higher as a result of both decreased renal clearance and increased production. Several factors, both dialysis-related (e.g., membrane bioincompatibility) and non-dialysis-related (e.g., infection, comorbidity, genetic factors, diet), may additionally contribute to a state of persistent inflammation. In addition to putative direct proatherogenic effects, persistent inflammation may serve as a catalyst and, in the uremic milieu, modulate the effects of risk factors for wasting and vascular disease (Carrero \& Stenvinkel, 2009). In the uremic milieu, in which cytokines are retained as a result of loss of residual renal function and stimulated by comorbidities and the dialysis procedure itself, such interactions should be of relevance.

As mentioned before, elevated C-Reactive Protein is associated with atherogenesis and endothelial dysfunction, and inflammation enhances cardiovascular risk and mortality in haemodialysis patients (Zimmermann et al., 1999). Tumor necrosis factor-alpha is increased in this process, and may synergize oxidative stress processes that lead to lipid peroxidation and oxidized LDL (Stenvinkel et al., 1999). Inflammation also might cause endothelial dysfunction through the stimulation of intracellular adhesion molecules in patients with chronic kidney disease as soluble Vascular Adhesion Molecule-1 (sVCAM-1) and soluble Intercellular Adhesion Molecule-1 (sICAM-1) (Stam et al., 2003).

Migration of monocytes into the vessel wall contributes to the onset and progression of atherosclerosis (Kon et al., 2011). The infiltration of monocytes and T lymphocytes in the vascular wall depends on the response to chemokines, and $\mathrm{CD} 14^{2+} \mathrm{CD}^{16+}$ monocytes are characterized by a unique pattern of chemokine receptors, represented by the chemokine 
receptor 5 (CCR5). In states of inflammation, CCR5 could contribute to atherogenesis through the binding of its ligands, which in turn mediate the recruitment of inflammatory cells to the endothelium (Carrero \& Stenvinkel, 2009).

Chronic kidney disease is a low-grade inflammatory process with peripheral polymorphonuclear leukocyte and $\mathrm{CD} 14^{+} / \mathrm{CD} 16^{+}$cells being key mediators in this process (Sela et al., 2005). In fact, persistent inflammation may also be a risk factor per se for progression of kidney disease, as inflammatory markers are predictors of kidney function deterioration. This could be a consequence of inflammatory mediators such as tumor necrosis factor-alpha or interleukin- 6 being able to act as toxins participating in uremia complications. In addition, C-Reactive protein formed locally in the renal inflammatory process reduces nitric oxide production, stimulates endothelin-1 formation, and induces some of the steps involved in the atherosclerosis process, as monocyte recruitment and foam cell formation (Labarrere \& Zaloga, 2004). Elevated C-Reactive protein, interleukin-6, and fibrinogen are independent predictors of cardiovascular outcomes in patients with kidney disease (Cachofeiro et al., 2008). Inflammation could promote both renal deterioration (triggering endothelial dysfunction, atherosclerosis, and glomerular injury) and cardiovascular mortality. Inflammation is a redox-sensitive mechanism, as oxidative stress is able to activate transcriptor factors such as Nuclear Factor-kappaB, which regulates inflammatory mediator gene expression (Li \& Karin, 1999). This nuclear factor is maintained inactivated in the cytoplasm by binding to inhibitory proteins. Their phosphorylation, posterior ubiquitination, and proteolysis result in the release and translocation of it to the nucleus and consequent activation of specific genes. Some of these steps seem to be affected by oxidative stress as the presence of antioxidants prevents nuclear factor-kappaB activation by reactive oxygen species (Li \& Karin, 1999).

The observation that both protein-energy wasting and persistent inflammation are highly prevalent in dialysis patients and are associated with a substantially increased mortality risk has focused on the endothelium as an important target (Carrero \& Stenvinkel, 2009). Because protein-energy wasting, inflammation, and atherosclerosis often coexist in the uremic milieu, these risk factors are linked. One of the main detrimental effects of proinflammatory cytokine activation in patients with end-stage renal disease is muscle depletion or sarcopenia, mediated by interleukin-6, angiotensin II and Tumor Necrosis Factor -like weak inducer of apoptosis (TWEAK) (Carrero et al., 2008).

The role of persistent inflammation as a culprit of converting the endothelium into a procoagulant and proinflammatory surface that makes the vasculature more vulnerable to the effects of other circulating risk factors is to be better determined. However, the strong associations between inflammatory markers and endothelial dysfunction in patients with chronic kidney disease support this hypothesis (Carrero \& Stenvinkel, 2009).

\subsection{The endothelium and uremic toxins}

During the development of the uremic syndrome, losses of kidney function are accompanied by deteriorating organ function attributable to the accumulation of uremic retention solutes. Compounds that exert an adverse biologic impact are called uremic toxins. At least 115 toxins accumulate in uremia and may play an important role in the pathogenesis of the uremic sindrome (Vanholder et al., 2008). Peptides in the 10- to 30-kD range, for example, are some of the so-called "middle molecules." These peptides can be glycosylated, oxidized, or carbamylated, thereby altering their structure and function so that 
cell and organ dysfunction may not simply result from accumulation of these metabolites. Uremic toxins provoke oxidative stress, inflammation, hypertrophy, constriction, and coagulation through various mechanisms. Monocytes, in response to advanced glycosylation end products that accumulate in uremia, produce free radicals that provoke oxidative stress. Monocytes, in response to leptin accumulation in uremia, cause clotting. Macrophages in response to homocysteine provokes oxidative stress. Finally, leukocytes are activated by the uremic toxin p-cresol sulfate. Platelets now are recognized to accumulate uremic toxins, and the interaction between platelets and vascular smooth muscle may lead to vascular smooth muscle growth and constriction, thereby contributing to both hypertension and atherosclerosis. The uremic toxins in platelets are collectively known as diadenosine polyphosphate. Both diadenosine pentaphosphate and diadenosine hexaphosphate are strongly protein bound and poorly removed by dialysis and produce vasoconstriction or vascular smooth muscle growth (Vanholder et al., 2010). Uremic toxins can activate the endothelium to produce the following effects: (1) vasoconstriction (via asymmetric dimethylarginine, advanced glycation end product, and homocysteine); (2) inflammation (via indoxyl sulfate and advanced glycation end products); (3) oxidative stress (via asymmetric dimethylarginine, advanced glycation end product, and homocysteine); (4) or procoagulant activity. The procoagulant effect of endothelium is noted by increased procoagulant factors (increased plasminogen activator inhibitor-1 and von Willebrand factor) and reduced anticoagulant factors (e.g., tissue plasminogen activator). It follows, then, that a diverse group of toxins act on a variety of cell types to provoke oxidative stress, inflammation, vascular smooth vessel proliferation and constriction, endothelial dysfunction, and coagulation, accounting for some of the manifestations of the uremic syndrome that include hypertension and accelerated atherosclerosis.

These low molecular weight organic compounds may either exist in free water- soluble forms or bind reversibly to serum proteins, thereby altering protein functions (Vanholder et al., 1992). In kidney disease, peptides may be found in their native form or, as a consequence of exposure to the uremic milieu, become irreversibly altered resulting in changes in structure and function. Importantly, both protein-bound solutes and peptides are particularly difficult to remove by conventional dialysis treatments, and uremic retention solutes may play a role in uremia-related complications (Vanholder et al., 2008). There have been described dual effects of uremic retention solutes on leukocyte function: Blunting upon stimulation, which has been linked to infection, and basal activation linked to microinflammation, malnutrition, and atherosclerosis. The major leukocyte subtypes affected by uremic conditions are polymorphonuclear cells, specifically neutrophils and mononuclear cells of the monocyte/macrophage type 2 . It is predominantly the latter cell type that is activated by uremic retention solutes, enhancing vascular damage (Vanholder et al., 2008).

Patients on haemodialysis have alterations in endothelial properties with increases in both plasminogen activator inhibitor- 1 and von Willebrand factor, whereas tissue plasminogen activator decreases, suggesting a procoagulant state at the endothelial surface (Haaber et al., 1995). Regulation of vascular tone is also impaired with decreased endothelium-dependent vasodilatation, associated with the aforementioned inhibition of endothelial nitric oxide synthase by asymmetric dimethylarginine, advanced glycation end-products and homocysteine. Chronic kidney disease also induces oxidant stress and inflammation in endothelial cells and production of reactive oxygen species in cultured endothelial cells by the protein-bound uremic toxin indoxyl sulfate. 
A new insight into endothelial dysfunction is also provided by the observation of circulating endothelial microparticles. The generation of endothelial microparticles is elicited in vitro by the presence of indoxyl sulfate (Faure et al., 2006). A remarkable characteristic of the endothelium is its capacity for continuous regeneration and repair. This involves two mechanisms: The classically described proliferation of adjacent endothelial cells and the more recently described homing of circulating endothelial progenitor cells (Vanholder et al., 2008). These latter cells may be mobilized from bone marrow in response to cytokines or ischemia or derive from circulating leukocytes. In haemodilaysis subjects, endothelial repair mechanisms are altered, representing a possible threat to vascular integrity. Some uremic toxins such as indoxyl sulfate reduce endothelial proliferation, and serum from uremic patients decreases the ability of endothelial progenitor cells to migrate. In addition, these patients generally have a decrease in the number of circulating endothelial progenitor cells (de Groot et al., 2004).

\subsection{The endothelium and haemostatic disturbances}

An important intermediary in the continued activation of endothelial cells is the interaction of the endothelium with platelets. The adhesion of platelets to activated endothelial cells is mediated by a glycoprotein IIb/IIIa-dependent mechanism. The activation of glycoprotein $\mathrm{IIb} / \mathrm{III}$ induces the expression of factors such as P-selectin that promote activation of the endothelium (May et al., 2002). Platelets recruit bone marrow-derived progenitor cells to the activated endothelium and the injured vessel wall by providing a surface that supports interaction between platelet P-selectin and the glycoprotein IIb/IIIa integrin (Rabelink et al., 2010). A relevant platelet-derived chemokine for the interaction of leukocytes with the activated endothelium is RANTES, secreted by thrombin-stimulated platelets and immobilized on the surface of the inflamed endothelium which triggers shear stressresistant monocyte arrest. (von Hundelshausen \& Weber, 2007). After their activation, membrane vesicles (0.1-1 $\mu \mathrm{m}$ in diameter) may be released from endothelial cells. Under normal conditions, phospholipid moieties in the plasma membrane are distributed asymmetrically. During microparticle formation, membrane asymmetry is lost, resulting in microparticles becoming procoagulant. (Rabelink et al., 2010). A variety of proinflammatory agents, including tumor necrosis factor, and procoagulant factors, such as thrombin, can induce the formation of endothelial microparticles. The biological effects of endothelial microparticles are largely determined by their protein and lipid composition. They might contain tissue factor, metabolic enzymes, proteins involved in adhesion and fusion processes, cytoskeleton associated proteins, or chemokines. Endothelial microparticles themselves can therefore contribute to the further activation of endothelial cells and to the initiation of coagulation, and may transfer endothelial proteins to circulating cells. Circulating levels of endothelial microparticles have been suggested to be a marker of sustained endothelial-cell activation. These circulating microparticles are elevated in dialysis patients (Mallat et al., 2000), and could be directly related to the presence of uremic toxins (Rabelink et al., 2010). The levels of endothelial microparticles in patients with end-stage renal disease positively correlate with endothelial dysfunction, as measured by flowmediated vasodilatation, and indices of arterial stiffening. Endothelial microparticles directly impair endothelium-dependent vasodilator mechanisms in dialysis subjects, while their low levels are associated with improved survival in this population. As mentioned before, platelets also play a central role in vascular damage by inducing haemostasis and arterial thrombosis (Vanholder et al., 2010). 
As discussed previously, platelets interact with coagulation factors, in particular thrombin, and during thrombin-induced aggregation, almost the entire content of platelet granules is released. Platelets from patients with renal failure have increased intracellular concentration of the diadenosine polyphosphates which act as strong growth factors for vascular smooth muscle cells. Because enhanced smooth muscle growth is a hallmark of atherosclerosis in renal failure, the increased amount of diadenosine polyphosphates in platelets may play an important role in causing increased cardiovascular damage. Furthermore, diadenosine polyphosphates are strong vasoconstrictors with direct effects on vascular tone (Vanholder et al., 2010). Thus, platelet-endothelium interaction may play an important role in hypertension and atherosclerosis in renal failure.

\subsection{The endothelium and protein-energy wasting}

There has been an increase of mechanisms causing syndromes of wasting, malnutrition, inflammation, and their interrelationships in individuals with chronic kidney disease. Approximately $18-75 \%$ of patients on chronic dialysis show evidence of wasting (Stenvinkel et al., 2004). This phenomenon has been referred to as uremic malnutrition, uremic cachexia, protein-energy malnutrition, malnutrition-inflammation atherosclerosis syndrome, or malnutrition-inflammation complex syndrome (Fouque et al., 2008). Many of the measures indicating the presence of wasting and abnormalities in protein-energy nutritional status can also be induced by inflammatory processes. As mentioned in previous sections, an increase in proinflammatory cytokines may cause loss of protein stores. The loss of muscle and fat stores and the present inflammation condition are likely to increase the risk of death from cardiovascular disease by promoting endothelial damage (Avesani et al., 2006). In kidney disease, there are conditions resulting in loss of lean body mass not related to reduced nutrient intake, due to nonspecific inflammatory processes, intercurrent catabolic illnesses, nutrient losses into dialysate, academia, resistance to anabolic hormones, hyperglucagonemia, hyperparathyroidism, use of prostheses, and anemia or its treatment (Fouque et al., 2008). Amongst the number of disorders that can cause wasting in patients with kidney disease, inflammation, oxidative stress, acidemia, nutrient losses into dialysate, anemia, hyperparathyroidism, and retention of uremic toxins interplay and, as shown in previous sections, cause endothelial dysfunction, leading to atherogenesis and cardiovascular disease). Elevated cardiovascular and haemodynamic markers of disease and endothelial stress as Pro-Brain Natriuretic Peptide or Troponin $T$ are associated with wasting and inflammation in haemodialysis subjects. The employment of vascular prostheses and catheters may play a role in this abnormal setting (Trimarchi et al., 2011).

\subsection{The endothelium, anemia and erythropoiesis-stimulating agents}

The association of anemia with cardiovascular outcomes is well known, but underlying mechanisms are not well understood (Jurkovitz et al., 2003). However, targeting a higher hemoglobin with higher doses of erythropoiesis-stimulating agents worsens cardiovascular outcomes in dialysis individuals (Singh et al., 2006) Possibilities include a higher prothrombotic state due to hypercoagulability or a potentially toxic effect of erythropoietic agents on the cardiovascular system.(Keithi-Reddy et al., 2008) As commented before, there exists a role for inflammation in atherosclerosis in kidney subjects. There is recent evidence that tumor necrosis factor-alpha is higher and the levels of serum albumin lower in anemic compared to non-anemic dialysis subjects. The levels of interleukins -6 and -8 , display increasing trends between anemic and non-anemic patients (Keithi-Reddy et al., 2008). 
These cytokines have been implicated as non-traditional cardiovascular risk factors associated with an increased risk of atherosclerosis. Interleukin-6 stimulate production of CReactive protein, while interleukin- 8 is a potent angiogenic factor that induces migration and proliferation of endothelial cells and smooth muscle cells contributing to plaque formation in atherosclerosis. (Simonini et al, 2000). One of the hypotheses promulgated to explain increased inflammation in chronic kidney disease patients is the reduced clearance of cytokines as renal function declines. Inflammatory cytokines interfere with both proliferation and differentiation of erythroid precursors by several mechanisms, including induction of apoptosis, downregulation of erythropoietin receptors, and reduced activity and synthesis of them (Weiss \& Goodnough, 2005). Besides, states of vascular congestion and chronic heart failure have been shown to have elevated levels of these inflammatory markers when the renal function declines. Of the inflammatory markers, interleukin- 6 is important by virtue of its actions not only on cardiovascular system but also on worsening of anemia.

However, the notion that oxygen transport capacity might increase at hematocrit values above $34 \%$ in patients with chronic renal disease is undetermined, because it has been known that when hematocrit values rise above $40 \%$ in normal subjects, oxygen transport capacity decreases as a result of the decrease in cardiac index associated with a rise in blood viscosity (Crowell \& Smith, 1967). The optimal hematocrit in dialysis patients has not been defined but may be lower than that in normal subjects because of decreased arterial and ventricular compliances and impaired cardiac index. Two controlled predialysis studies (CHOIR and CREATE), which compared traditional hematocrit targets of $34 \%$ to fully normalized targets, reported either no improvement in quality of life or that increased erythropoietin dosing resulted in increased cardiovascular adverse events or hypertension (Singh et al., 2006). The mechanisms responsible for these excess cardiovascular and mortality events are not fully elucidated, but erythropoietin-stimulating agents-induced arterial hypertension is a candidate (Krapf \& Hulter, 2009). The increase in systolic and diastolic blood pressure at the target hematocrit varied but reached an average of approximately 5 to $8 \mathrm{mmHg}$ in systolic and 4 to $6 \mathrm{mmHg}$ in diastolic blood pressure. Erythropoietin doses of 40, 80, and $120 \mathrm{U} / \mathrm{kg}$ thrice weekly for 49 weeks were associated with hypertension in $28 \%, 32 \%$, and $56 \%$ of treated subjects, respectively (Krapf \& Hulter, 2009). Erythropoietin induced hypertension is independent of its effect on red blood cell mass and viscosity is supported by the demonstration in rats that coadministration of erythropoietin with either a synthetic erythropoietin binding protein or an antierythropoietin antibody prevented erythropoietin-induced hypertension while preserving the erythropoietic response. This suggests the interesting possibility that different epitopes on the erythropoietin protein confer independent erythropoietic and haemodynamic effects. Erythropoietin induces endothelin-1 release and produces an enhanced mitogenic response in endothelial cells (Krapf \& Hulter, 2009). Production of the vasodilating prostacyclin is decreased and the vasoconstricting prostanoid thromboxaneB2 is increased. In human endothelial cells, erythropoietin decreases e nitric oxide synthase expression resulting in decreased endothelial nitric oxide production. The mechanism may include increased production of reactive oxygen species and asymmetric dimethylarginine (Scalera et al., 2005). A systemic effect to blunt endothelial nitric oxide production, combined with the increased endothelin-1 response and predominance of thromboxane over prostacyclin could explain the erythropoietin-induced vasoconstrictive effect (Krapf \& Hulter, 2009). Moreover, at least a subset of haemodialyzed patients exhibit an accentuated hypersensitivity to 
angiotensin II and norepinephrine during erythropoietin treatment, which correlated with an increase in blood pressure (Krapf \& Hulter, 2009). Thus, erythropoietin-induced hypersensitivity to angiotensin II and norepinephrine, as well as increased endothelin-1 activity, are reasonable mechanisms for erythropoietin-induced hypertension in haemodialyzed patients, in part impairing endothelial relaxation (Annuk et al., 2006).

Interestingly, anemic patients treated with erythropoietin compared to erythropoietin-naive patients revealed increased levels for interleukins- 6 and -8 , C-Reactive protein, and tumor necrosis factor-alpha. Although the antiapoptotic effect of erythropoietin on erythroid precursors in the bone marrow is well described, its potential effect of on cytokines is less well understood (Krantz, 1991). Long-term administration of erythropoietin has been associated with decreased levels of tumor necrosis-alpha in subjects on haemodialysis, but also to enhance inflammation and ischemia-induced neovascularization by increasing the mobilization of endothelial progenitor cells (Heeschen, et al., 2003). Furthermore, erythropoietin activates vascular smooth muscle cells, endothelium, and platelets enhancing thrombogenity and loss of vasodilatory potential. An alternative hypothesis is that induction of proinflammatory cytokines by erythropoietin occurs as a consequence of acting via erythropoetin receptors on macrophages, which upon activation secrete interleukin-6,-8, and tumor necrosis-alpha, leading to chronic inflammation, protein-energy wasting and atherogenesis. Indeed, these molecules have been associated with an increased risk of death in the dialysis population ( Keithi-Reddy et al., 2008). In addition, this could be one explanation for the observation of increased risk for all-cause and cardiovascular mortality in patients targeted to higher hemoglobin levels with higher doses of erythropoiesis stimulating agents (Singh et al., 2006)

\subsection{The endothelium and vascular calcification and ossification}

Vascular calcification is responsible for the higher prevalence of cardiovascular disease in dialysis patients. Consequently, its early detection is truly relevant in this population. Traditionally, it has been described as a patchy-like and/or a linear calcification that corresponds to intima (atherosclerosis-related) and media calcification (related to calcium/ phosphorus disturbances). However, there is a current debate about the location of calcium in the artery wall and their clinical implications, as referred before (Coll et al., 2011). Calcified plaques and intima calcification appear to be the most prevalent coronary abnormalities in advanced chronic kidney disease patients, and only a small proportion present media calcification. The pattern of linear calcification is highly associated with atherosclerosis (Coll et al., 2011). Vascular calcification has been historically classified as (1) intima calcification associated with atheroma plaques and (2) medial calcification mediated by a switch of vascular smooth muscle cells to a procalcification phenotype and associated with kidney disease and disturbances in the metabolism of calcium, phosphorus, and vitamin D (Cardús et al., 2006). However several potential flaws associated with this traditional view present: First, large arteries are "elastic" arteries functioning as blood conduits, and as such have a low content of smooth muscle cells. On the contrary, small, peripheral arteries are aimed at the regulation of blood flow in the tissue, presenting a dense layer of smooth muscle cells. Traditionally it is stated that large arteries are more prone to atherosclerosis, while small vessels are more prone to calcify. Moreover, the anatomic location of calcium in the artery wall presents a singular pattern that corresponds to the calcification of the internal elastic lamina. Conversely, medial calcification is related to the 
control of metabolic disturbances in terms of calcium, phosphorus, and vitamin D. However, low serum phosphorus is a protective factor for developing linear calcification, underscoring the influence of phosphorus on atherosclerosis. Therefore, vascular calcification in large arteries is more prevalent in dialysis patients than in controls, and it is predominantly a linear pattern located in the lumen-intima interphase. Age, dialysis, past medical history of cardiovascular disease, atherosclerosis, and inflammation are variables significantly influencing calcification (Coll et al., 2011).

Recently, the term ossification rather than calcification of both the arterial intima and media has been proposed for kidney subjects (Stenvinkel et al., 2008). The presence of artery ossification is associated with functional estimates of arterial dysfunction, such as nitric oxide-dependent vasodilatation in dialysis patients and pulse-wave velocity (Raggi et al., 2007). Vascular ossification should be considered as a cardiovascular risk marker and not an etiological factor of cardiovascular disease in chronic kidney disease (Stenvinkel et al, 2008). Multiple new biomarkers for early detection of arterial intima and/or media ossification have emerged. Serum levels of calcium and phosphorus have become established risk markers (Block et al., 2005). Hyperparathyroidism has also been suggested as a risk factor for and a marker of vascular ossification (Stevens et al., 2004), and Vitamin D deficiency is associated with increased early mortality. The best studied inhibitor of vascular ossification is fetuin-A, the major carrier of calcium ions in the circulation. Only in chronic kidney patients stage 5 low levels of fetuin-A are associated with adversed cardiovascular outcomes (Hermans et al., 2007). The ossification regulators matrix-Gla protein, bone morphogenic proteins, osteopontin, and osteoprotegerin, promote an early and extensive vascular ossification process, and have been shown to interfere with endothelial function by decreasing nitric oxide production and altering the normal anatomic vessel wall, rendering the endothelial surface prone to calcium deposition, prothrombotic events and a more rigid vessel wall (Hofbauer et al., 2007).

\section{The endothelium and haemodialysis}

Endothelial dysfunction is the initial pathophysiologic step in the progression of vascular damage that precedes and leads to clinically manifest cardiovascular diseases (Vita \& Keany, 2002). Endothelial dysfunction is highly prevalent in patients with advanced chronic kidney disease (Endermann \& Schiffrin, 2004) and is linked to the elevated cardiovascular risk of this patient population (Tonelli \& Pfeffer, 2007). The cause of endothelial dysfunction is complex and involves dysregulation of multiple pathways (Yilmaz et al., 2009).

\subsection{Haemodialysis components and endothelial damage}

Haemodialysis therapy may induce activation of complement and polymorphonuclear leukocytes, monocytes, or lymphocytes, depending on the dialyzer membrane used. The clinical situation is further complicated by the accumulation of uremic retention solutes and toxins, often inadequately removed during the dialysis schedule. Haemodialysis patients display evidence of elevated interleukin- 1 and tumor necrosis factor-alpha release, which is followed by the stimulated secretion of interleukin-6, responsible for acute-phase protein synthesis. High levels of the circulating proinflammatory cytokines interleukins-1, -6, -13 and tumor necrosis factor-alpha are associated with mortality in hemodialysis patients (Hörl, 2002). Essential functions of polymorphonuclear leukocytes-that is, phagocytosis, 
oxygen species production, upregulation of specific cell surface receptor proteins, or apoptosis - are disturbed in uremia. Clinical signs and symptoms of end-stage renal disease patients are at least in part related to the accumulation of middle molecules such as beta 2microglobulin, parathyroid hormone, advanced glycation end products, advanced lipoxidation end products, advanced oxidation protein products (formed as a result of oxidative stress, carbonyl stress, or both), granulocyte inhibitory proteins, or leptin. Currently available membrane materials do not provide long-lasting, effective reduction of middle molecules in patients who require maintenance haemodialysis (Hörl, 2002).

During haemodialysis, contact of blood with the dialyzer and dialysate also activates the kallikrein-kinin system and also induces the above mentioned inflammatory response. (Marney et al, 2009). These cytokines stimulate plasminogen activator inhibitor-1, the major physiologic inhibitor of fibrinolysis. Activation of the kallikrein-kinin could have favorable or deleterious effects on inflammation and the risk of cardiovascular events through endothelial damage. First, bradykinin causes vasodilation and stimulates the release of tissue-plasminogen activator from the endothelium, and infused bradykinin inhibits platelet aggregation. Conversely, bradykinin stimulates the inflammatory response and may have implications in atherothrombotic events in hemodialysis. Endogenous bradykinin contributes to hypotension, increased inflammation, increased oxidative stress, and increased fibrinolysis in response to haemodialysis (Marney et al., 2009).

Enhanced production of proinflammatory cytokines by dialysate pyrogens, by complement activation, or both, as well as inhibition of anti-inflammatory cytokine secretion, may contribute to the cell-mediated immunosuppression seen in dialysis patients. The presence of low and high molecular weight inhibitors of neutrophils in the plasma of uremic patients may explain, at least in part, why infections are a common cause of hospitalization and the second most common cause of death in these patients. Other middle molecules accumulate, and proteins are modified by oxidative stress, carbonyl stress, or both, contributing to the uremic syndrome.

\subsection{Haemodialysis and endothelial function improval}

Dialysis patients frequently present with endothelial dysfunction and a higher risk of developing atherosclerosis. Factors that impair endothelial function include lipid abnormalities, hyperhomocysteinemia, and the accumulation of inhibitors of nitric oxide synthesis (Trimarchi et al., 2002). Endothelial dysfunction can be detected long before atherosclerosis arises (Vanhoutte, 1988), and on ocassions can be improved by appropriate haemodialysis delivery (McGregor et al., 2003). Haemodialysis itself can reduce plasma endothelin-1 levels and increase the vasodilator endothelium-derived adrenomedullin (McGregor et al., 2003), which vasodilatory action is in part nitric oxide dependent (Majid et al., 1996). Asymmetric dimethyl-arginine, the nitric oxide antagonist that is elevated in uremia, can be cleared by dialysis (McGregor et al., 2003).

One of the most serious haemodynamic complications of uremia is hypotension. Symptomatic hypotension occurs in approximately $25 \%$ of haemodialysis sessions, and can restrict the amount of fluid to be removed. Many mechanisms have been proposed: Abnormalities of the response of resistance and capacitance vessels to hypovolemia and disbalanced reflex increases in peripheral vascular resistance to hypovolemia have been implicated (Hand et al., 1998). The endothelium adequate response is also altered by the uremic toxins that accumulate and by the abnormal cellular and chemical reactions between 
platelets, leukocytes and the endothelial cell itself. When appropriately performed and delivered, haemodialysis sessions may improve endothelial function by improving the internal milieu and by removing the toxins and inflammatory mediators that can interfere with the normal endothelium-derived vasomodulator activity (Hand et al., 1998, McGregor et al., 2003), albeit some studies have failed to support this finding (Pupim et al., 2004). Finally, as endothelial cells are highly sensitive to extracellular sodium and potassium, the chemical derangement that rules in renal failure alters the endothelial-mediated regulation of local blood flows. This effect may also has pathophysiological relevance in the development of hypertension and atherosclerosis in haemodialysis subjects (Oberleithner et al., 2010).

\section{Conclusions}

The endothelium is a vital organ that dynamically interacts with the whole economy, managing vital activities through the mediators it synthesizes and releases in an endocrine and paracrine fashion. It plays a main role in vascular tone and metabolic pathways. In haemodialysis, endothelial dysfunction can be caused by several factors or worsen them: Oxidative stress, inflammation, haemostatic derangements, protein-energy wasting, vascular calcification, anemia, molecular alterations and the dialytic procedure itself. They are strongly interrelated and play a major role in the initiation and progression of vascular complications, leading to the high mortality rate cardiovascular disease presents in dialysis.

\section{References}

Abderrahim-Ferkoune, A.; Bezy, O.; Chiellini, C.; Maffei, M., Grimaldi, P.; Bonino, F.; Moustaid-Moussa, N., Pasqualini, F.; Mantovani, A.; Ailhaud, G. \& Amri E. (2003). Characterization of the Long Pentraxin PTX3 as a TNF-alpha-induced Secreted Protein of Adipose Cells. The Journal of Lipid Research, Vol. 44, No.5, (May 2003), pp 994-1000, ISSN 0022-2275

Anavekar, NS. \& Pfeffer, MA. (2004). Cardiovascular Risk in Chronic Kidney Disease. Kidney International, Vol. 92, Suppl.92, (November 2004), pp 11- 15, ISSN 0085-2538

Andrew, PJ. \& Mayer, B. Enzymatic Function of Nitric Oxide Synthases. (1999). Cardiovascular Research, Vol.43, No.3, (August 1999), pp 521-531, ISSN 0008-6363

Annuk M, Linde T, Lind L, Fellstrom B: Erythropoietin Impairs Endothelial Vasodilatory Function in Patients with Renal Anemia and in Healthy Subjects. (2006). Nephron Clinical Practice, Vol.102, No.1, (January 2006), pp 30-34, ISSN 1660-2110

Avesani, CM.; Carrero, JJ.; Axelsson, J.; Qureshi, AR.; Lindholm, B. \& Stenvinkel, P. (2006). Inflammation and Wasting in Chronic Kidney Disease: Partners in Crime. Kidney International, Vol.70, Suppl., (2006), pp 8-13, ISSN 0085-2538

Block, GA.; Spiegel, DM.; Ehrlich, J; Mehta, R.; Lindbergh, J.; Dreisbach, A. \& Raggi P. (2005) Effects of Servelamer and Calcium on Coronary Artery Calcification in Patients New to Hemodialysis. Kidney International, Vol.68, No.4, (October 2005), pp 18151824, ISSN 0085-2538

Blokhina, O.; Virolainen, E. \& Fagerstedt, KV. (2003). Antioxidants, Oxidative Damage and Oxygen Deprivation Stress: a Review. Annals of Botany, Vol.91, No.2, (January 2003), pp 179-194, ISSN 0305-7364 
Boehme, M.; Kaehne, F.; Kuehne, A; Bernhardt, W.; Schroder, M.; Pommer, W.; Fischer, C.; Becker, H.; Muller, C. \& Schindler, R. (2007). Pentraxin 3 is Elevated in Haemodialysis Patients and is Associated with Cardiovascular Disease. Nephrology Dialysis and Transplantation, Vol.22, No.8, (August 2007), pp 2224-2229, ISSN 09310509

Cachofeiro, V.; Goicochea, M.; García de Vinuesa, S.; Oubiña, P.; Lahera, V. \& Luño, J. (2008). Oxidative Stress and Inflammation, a Link between Chronic Kidney Disease and Cardiovascular Disease. Kidney International, Vol. 74, Suppl111, (December 2008), pp 4-9, ISSN 0085-2538

Cardús, A.; Parisi, E.; Gallego, C.; Aldea, M.; Fernández, E. \& Valdivielso, JM. (2006). 1,25Dihydroxyvitamin D3 Stimulates Vascular Smooth Muscle Cell Proliferation through a VEGF-mediated Pathway. Kidney International, Vol. 69:, No.8, (April 2006), pp 1377-1384, ISSN 0085-2538

Carrero, JJ.; Chmielewski, M,; Axelsson, J.; Snaedal, S.; Heimbürger, O.; Bárány, P.; Suliman, ME.; Lindholm, B.; Stenvinkel, P. \& Qureshi, AR. Muscle Atrophy, Inflammation and Clinical Outcome in Incident and Prevalent Dialysis Patients. Clinical Nutrition, Vol.27, No.4, (August 2008), pp 557-564, ISSN 0954-3007

Carrero, JJ. \& Stenvinkel, P. (2009). Persistent Inflammation as a Catalyst for Other Risk Factors in Chronic Kidney Disease: A Hypothesis Proposal. Clinical Journal of the American Society of Nephrology, Vol.4, Suppl.1, (December 2009), pp 49-55, ISSN 1555-9041

Castro, R; Rivera, I; Struys, EA.; Jansen, EEW,; Ravasco, P:; Camilo, ME:; Blom, KJ., Jakobs, C. \& De Almeida, IT. (2003). Increased Homocysteine and S-adenosylhomocysteine Concentrations and DNA Hypomethylation in Vascular Disease. Clinical Chemistry, Vol. 49, No.8, (August 2003), pp 1292-1296, ISSN 1434-6621

Cines, DB.; Pollak, ES.; Buck, CA.; Loskalzo, J.; Zimmermann, GA.; Mc Ever, RP.; Pober, JS.; Wick, TM.; Konkle, BA.; Schwartz BS, Barnathan, ES.; Mc Krae, KR.; Hug, BA.; Schmidt, AM. \& Stern DM. (1998). Endothelial Cells in Physiology and in Pathophysiology of Vascular Disorders. Blood, Vol.91, No.10, (May 1998), pp 35273561, ISSN 0006-4971

Clozel, M \& Fischli, W. (1989). Human Cultured Endothelial Cells Do Secrete Endothelin-1. Journal of Cardiovascular Pharmacology, Vol.13, Suppl. 5, (January 1989), pp 193-196, ISSN 0160-2446

Coll, B.; Betriu, A.; Martínez-Alonso, M.; Amoedo, ML.; Arcidiacono, MV.; Borras, M.; Valdivielso, JM. \& Fernández, E. (2011). Large Artery Calcification on Dialysis Patients Is Located in the Intima and Related to Atherosclerosis. Clinical Journal of the American Society of Nephrology, Vol.6, No.2, (February 2011), pp 303-310, ISSN 1555- 9041

Crowell, JW. \& Smith, EE. (1967). Determinant of the Optimal Hematocrit. Journal of Applied Physiology, Vol.22, No.3 (March 1967), pp 501-504, ISSN 8750-7587

de Groot, K.; Bahlmann, FH.; Sowa, J.; Koenig, J.; Menne, J.; Haller, H. \& Fliser, D. (2004). Uremia Causes Endothelial Progenitor Cell Deficiency. Kidney International, Vol.66, No.2, (August 2004), pp 641-646, ISSN 0085-2538

de Zeeuw, D. (2007). Albuminuria: A Target for Treatment of Type 2 Diabetic Nephropathy. Seminars in Nephrology, Vol. 27, No.2, (March 2007), pp 70-74, ISSN 0270-9295 
Dong, C.; Yoon, W. \& Goldschmidt-Clermont, PJ. (2002). DNA Methylation and Atherosclerosis. Journal of Nutrition, Vol.132, No.8 Suppl., (August 2002), pp 24062409, ISSN 0022-3166

Endemann, DH. \& Schiffrin, EL. (2004). Endothelial Dysfunction. Journal of the American Society of Nephrology, Vol.15, No.8 (August 2004), pp 1983-1992, ISSN 1046-6673

Esmon, CT.; CT.; Fukudome, K.; Mather, T, Bode, W.; Regan, LM.; Stearns-Kurosawa, DJ. \& Kurosawa, S. (1999). Inflammation, Sepsis, and Coagulation. Haematologica, Vol.84, No.3, (March 1999), pp 254-259, ISSN 0390-6078

Faure, V.; Dou, L.; Sabatier, F.; Cerini, C.; Sampol, J.; Berland, Y.; Brunet, P. \& DignatGeorge, F. (2006). Elevation of Circulating Endothelial Microparticles in Patients with Chronic Renal Failure. Journal of Thrombosis and Haemostasis, Vol.4, No.3, (March 2006), pp 566-573, ISSN 1538-7836

Festa, A.; D’Agostino, R.; Howard, G.; Mykkanen, L.; Tracy, RP. \& Haffner, SM. (2000). Inflammation and Microalbuminuria in Non-Diabetic and Type 2 Diabetic Subjects: The Insulin Resistance Atherosclerosis Study. Kidney International, Vol. 58, No.4, (October 2000), pp 1703-1710, ISSN 0085-2538

Fishbein, G.A. \& Fishbein, M.C. (2009). Arteriosclerosis: Rethinking the Current Classification. Archives of Patholgy and Laboratory Medicine, Vol.133, No.8: (August 2009), pp 1309-1316, ISSN 0003-9985

Frick, M. \& Weidinger F. (2007). Endothelial Function: A Surrogate Endpoint in Cardiovascular Studies?. Current Pharmaceutical Design, Vol.13, No.17 (June 2007), pp 1741-1750, ISSN 1381-6128

Fouque, D.; Kalantar-Zadeh, K.; Kopple, J.; Cano, N.; Chauveau, P.; Cuppari, L.; Franch, H.; Guarnieri, G.; Ikizler, TA.; Kaysen, G.; Lindholm, B.; Massy, Z.; Mitch, W.; Pineda, E.; Stenvinkel, P.; Trevinho-Becerra, A. \& Wanner,C. (2008). A Proposed Nomenclature and Diagnostic Criteria for Protein-Energy Wasting in Acute and Chronic Kidney Disease. Kidney International, Vol.73, No.4, (February 2008), pp 391398, ISSN 0085-2538

Goligorsky, MS. (2007). Frontiers in Nephrology: Viewing the Kidney through the HeartEndothelial Dysfunction in Chronic Kidney Disease. Journal of the American Society of Nephrology, Vol.18, No.11, (November 2007), pp 2833-2835, ISSN 1046-6673

Guérin, A.P.; Pannier, B.; Métvier, F.; Marchais, S.J. \& London, G.M. (2008). Assessment and Significance of Arterial Stiffness in Patients with Chronic Kidney Disease. Current Opinion in Nephrology \& Hypertension, Vol.17, No.6, (November 2008), pp 635-641, ISSN 1062-4821

Haaber, AB.; Eidemak, I.; Jensen, T.; Feldt-Rasmussen, B. \& Strandgaard, S. (1995). Vascular Endothelial Cell Function and Cardiovascular Risk Factors in Patients with Chronic Renal Failure. Journal of the American Society of Nephrology, Vol.5, No.8, (February 1995), pp 1581-1584, ISSN 1046-6673

Hand, MF.; Haynes, WG. \& Webb DJ. (1998). Hemdoialysis and L-arginine, but not Darginine, Correct Renal Failure-Associated Endothelial Dysfunction. Kidney International, Vol.53, No.4, (April 1998), pp 1068-1077, ISSN 0085-2538

Handelman, GJ.; Walter, MF.; Adhikarla, R.; Gross, J.; Dallal, DE.; Levin, NW.; Blumberg, JV. (2001). Elevated Plasma F2-Isoprostanes in Patients on Long-Term Hemodilaysis. Kidney International, Vol.59, No.5, (May 2001), pp 1960-1966, ISSN 0085-2538 
Heeschen, C.; Aicher, A.; Lehmann, R.; Fichtlscherer, S.; Vasa, M.; Urbich, C.; Mildner-Rihm, C; Martin, H.; Zeiher, AM. \& Dimmeler, S. (2003). Erythropoietin is a Potent Physiologic Stimulus for Endothelial Progenitor Cell Mobilization. Blood, Vol.102, No.4, (August 2003), pp 1340-1346, ISSN 0006-4971

Herbrig, K.; Pistrosch, F.; Oelschlaegel, U.; Wichmann, G.; Wagner, A.; Foerster, S.; Richter, S.; Gross, P. \& Passaurer, J. (2004). Increased Total Number but Impaired Migratory Activity and Adhesion of Endothelial Progenitor Cells in Patients on Long-Term Hemodialysis. American Journal of Kidney Diseases, Vol. 44, No.5, (November 2004), pp 890-894, ISSN 0272-6386

Hermans, MM.; Brandenburg, V.; Ketteler, M.; Kooman, JP.; van der Sande, FM.; Boeschoten, EW.; Leunissen, KM.; Krediet, RT. \& Dekker, FW. (2007). Association of Serum Fetuin-A Levels with Mortality in Dialysis Patients. Kidney International, Vol.72, Vol.2, (July 2007), pp 202-207, ISSN 0085-2538

Hill, JM.; Zalos, G.; Halcox, JPJ.; Schenke, WH.; Waclawiw. MA; Quyyumi, AA. \& Finkel, T. (2003). Circulating Endothelial Progenitor Cells, Vascular Function, and Cardiovascular Risk. New England Journal of Medicine, Vol. 348, No.7, (February 2003), pp 593-600, ISSN 0028-4793

Himmelfarb, J.; Stenvinkel P.; Alp Ikizler, T.; \& Hakim, RH. (2002). The Elephant in Uremia: Oxidant Stress as a Unifying Concept of Cardiovascular Disease in Uremia. Kidney International, Vol.62, No.5 (November 2002), pp 1524-1538, ISSN 0085-2538

Himmelfarb, J.; McMenamin, E.; Loseto, G. \& Heinecke, JW. (2001). MyeloperoxidaseCatalyzed 3-Chlorotyrosine Formation in Dialysis Patients. Free Radical Biology $\mathcal{E}$ Medicine, Vol. 31, No.10, (November 2001), pp 1163-1169, ISSN 0891-5849

Hofbauer, LC.; Brueck, CC.; Shanahan, CM.; Schoppet, M. \& Dobnig, H (2007). Vascular Calcification and Osteoporosis: From Clinical Observation Towards Molecular Understanding. Osteoporosis International, Vol.18, No.3, (March 2007), pp 251-259, ISSN 0937-941X

Hörl WH. (2002). Hemodialysis Membranes: Interleukins, Biocompatibility, and Middle Molecules. Journal of the American Society of Nephrology, Vol. 13, Suppl.1, (January 2002), pp 62-71, ISSN 1046-6673

Huber, K. (2001). Plasminogen Activator Inhibitor Type-1 (part one): Basic Mechanisms, Regulation and Role for Thromboembolic Disease. Journal of Thrombosis and Thrombolysis, Vol.11, No.3, (May 2001), pp 183-193, ISSN 0929-5305

Ix, JH.; Shiplak, MG.; Sarnak, MJ.; Beck GJ.; Greene, T.; Wang, X; Kusek, JW, Collins, AJ; Levey, AS. \& Menon, V. (2007). Fetuin-A Is Not Associated with Mortality in Chronic Kidney Disease. Kidney International, Vol.72, No.11, (December 2007), pp 1394-1307, ISSN 0085-2538

Jurkovitz, CT.; Abramson, JL.; Vaccarino, LV.; Weintraub, WS. \& McClellan, WM. (2003). Association of High Serum Creatinine and Anemia Increases the Risk of Coronary Events: Results from the Prospective Community-Based Atherosclerosis Risk in Communities (ARIC) study. Journal of the American Society of Nephrology, Vol.14, No.11, (November 2003), pp 2919-2925, ISSN 1046-6673

Kahler, J.; Ewert, A.; Weckmüller, J.; Stobbe, S.; Mittmann, C.; Köster, R.; Paul, M.; Meinertz, T. \& Münzel, T. (2001). Oxidative Stress Increases Endothelin-1 Synthesis in Human Coronary Artery Smooth Muscle Cells. Journal of Cardiovascular Pharmacology, Vol.38, No.1, (July 2001), pp 49-57, ISSN 1074-2484 
Keithi-Reddy, SR.; Addabbo, F.; Patel, TV.; Mittal, BV.; Goligorsky, MS. \& Singh, AK. (2008). Association of Anemia and Erythropoiesis Stimulating Agents with Inflammatory Biomarkers in Chronic Kidney Disease. Kidney International, Vol.74, No.6, (September 2008), pp 782-790, ISSN 0085-2538

Kielstein, J. \& Zoccali, C. (2005). Asymmetric Dimethylarginine: A Cardiovascular Risk Factor and a Uremic Toxin Coming of Age?. American Journal of Kidney Diseases, Vol.46, No.2, (August 2005), pp 186-202, ISSN 0272-6386

Koc, M.; Richards, HB.; Bihorac, A.; Ross, EA.; Schold, JD. \& Segal, MS. (2005). Circulating Endothelial Cells Are Associated with Future Vascular Events in Hemodialysis Patients. Kidney International, Vol.67, No.3, (March 2005), pp 1079-1083, ISSN 00852538

Kon, V.; MacRae, F.; Fazio, L \& Fazio, S. (2011). Atherosclerosis in Chronic Kidney Disease: the Role of Macropahges. Nature Reviews Nephrology, Vol.7, No.1, (January 2011), pp 45-54, ISSN 1759-5061

Krapf, R. \& Hulter, HN. (2009). Arterial Hypertension Induced by Erythropoietin and Erythropoiesis-Stimulating Agents (ESA). Clinical Journal of the American Society of Nephrology, Vol. 4, No.2, (February 2009), pp 470-480, ISSN 1046-6673

Kuijper, PHM.; Gallardo-Torres, HI; van der Linden, JAM.; Lammers JWJ.; Sixma, JJ.; Koenderman, L. \& Zwaginga, JJ. (1996). Platelet-Dependent Primary Haemostasis Promotes Selectin- and Integrin-Mediated Neutrophil Adhesion to Damaged Endothelium under Flow Conditions. Blood, Vol.87, No.8, (April 1996), pp 32713281, ISSN 0006-4971

Krantz, SB. (1991). Erythropoietin. Blood, Vol.77, No.3, (February 1991), pp 419-434, ISSN 0006-4971

Labarrere, CA. \& Zaloga, GP. (2004). C-Reactive Protein: from Innocent Bystander to Pivotal Mediator of Atherosclerosis. American Journal of Medicine, Vol.117, No.7, (October 1999), pp 499-507, ISSN 0002-9343

Li, N. \& Karin, M. (1999). Is NF-KB the Sensor of Oxidative Stress?. The Journal of the Federation of American Societies for Experimental Biology, Vol.13, No.10, (July 1999), pp 1137-1143, ISSN 0892-6638

Linden, E.; Cai, W.; He, JC.; Xue, C; Li, Z; Winston, J; Vlassara, H. \& Uribarri, J. (2008). Endothelial Dysfunction in Patients with Chronic Kidney Disease Results from Advanced Glycation End Products (AGE)-Mediated Inhibition of Endothelial Nitric Oxide Synthase Through RAGE Activation. Clinical Journal of the American Society of Nephrology, Vol. 3, No.3, (May 2008), pp 691-698, ISSN 1555- 9041

London, G.M. \& Drüeke, T.B. (1997). Atherosclerosis and Arteriosclerosis in Chronic Kidney Failure. Kidney International, Vol.51, No.6 (June 1997), pp 1678-1695, ISSN 0085-2538

Majid, DS.; Kadowitz, PJ.; Coy, DH. \& Navar, LG. (1996). Renal Responses to Intra-Arterial Administration of Adrenomedullin in Dogs. American Journal of Physiology, Vol.270, No.1, (January 1996), ppF200-F205, ISSN 0363-6119

Mallat, Z.; Benamer, H.; Hugel, B.; Benessiano, J.; Steg, PG.; Freyssinet, JM. \& Tedgui, A. (2000.) Elevated Levels of Shed Membrane Microparticles with Procoagulant Potential in the Peripheral Circulating Blood of Patients with Acute Coronary Syndromes. Circulation, Vol.101, No.8, (February 2000), pp 841-843, ISSN 0009-7322

Marney, AM.;Ma, J.; Luther,JM.; Ikizler, TA. \& Brown, NJ. (2009). Endogenous Bradykinin Contributes to Increased Plasminogen Activator Inhibitor 1 Antigen following 
Hemodialysis. Journal of the American Society of Nephrology, Vol. 20, No.10, (October 2009), pp 2246-2252, ISSN 1046-6673

Massy, ZA.; Borderie, D.; Nguyen-Khoa, T.; Drüeke, TB.; Ekindjian, OG. \& Lacour, B. (2003). Increased Plasma S-Nitrosothiol Levels in Chronic Haemodialysis Patients. Nephrology Dialysis and Transplantation, Vol.18, No.1, (January 2003), pp 153-157, ISSN 0931-0509

May, AE.; Kälsch, T.; Massberg, S.; Herouy, Y.; Schmidt, R. \& Gawaz, M. (2002). Engagement of Glycoprotein IIb/IIIa (alpha(IIb)beta3) on Platelets Upregulates CD40L and Triggers CD40L-Dependent Matrix Degradation by Endothelial Cells. Circulation, Vol.106, No.16, (October 2002), pp 2111-2117, ISSN 0009-7322

Meltivier, F. (2007). Mineral Metabolism and Arterial Functions in End-Stage Renal Disease: Potential Role of 25-hydroxyvitamin D Deficiency. Journal of the American Society of Nephrology, Vol.18, No.2, (February 2007), pp 613-620, ISSN 1046-6673

Mackay, CR. \& Imhof, BA. (1993). Cell Adhesion in the Immune System. Immunology Today, Vol.14, No.3, (March 1993), pp 99-102, ISSN 0167- 5699

McEniery, CM.; McDonnell, BJ.; So, A.; Aitken, S.; Bolton, CE.; Munnery, M.; Hickson, SS; Yasmin, S; Maki-Petaja, KM.; Cockcroft, JR.; Dixon, AK. \&, Wilkinson, IB. (2009). Aortic Calcification is Associated with Aortic Stiffness and Isolated Systolic Hypertension in Healthy Individuals. Hypertension, Vol.53, No.3, (March 2009), pp 524-531, ISSN 1933-1711

McGregor,D.; Buttimore, A; Lynn, K.; Yandle, T. \& Nicholls, M. (2003). Effects of Long and Short Hemodialysis on Endothelial Function: A Short-Term Study. Kidney International, Vol.63, No.2 (February 2003), pp 709-715, ISSN 0085-2538

Müller, MM. \& Griesmacher, A. (2000). Markers of Endothelial Dysfunction. Clinical Chemistry and Laboratory Medicine, Vol.38, No.2, (February 2000), pp 77-85, ISSN 1434-6621

Mulvihill, NT; Foley, JB.; Crean, P. \& Walsh, M. (2002). Prediction of Cardiovascular Risk Using Soluble Cell Adhesion Molecules. European Heart Journal, Vol.23, No.20, (October 2002), pp 1569-1574, ISSN 1522-9645

Navar, LG.; Harrison-Bernard, LM.; Nishiyama, A. \& Kobori, H. (2002). Regulation of Intrarenal Angiotensin II in Hypertension. Hypertension, Vol.39, No.2, (February 2002), pp 316-322, ISSN 1062-4821

Oberg, B.; McMenamin, E.; Lucas, F.; McMonagle, E.; Morrow, J.; Iklizer, T \& Himmelfarb, J. (2004). Increased Prevalence of Oxidant Stress and Inflammation in Patients with Moderate to Severe Chronic Kidney Disease. Kidney International, Vol. 65, No.3 (March 2004), pp 1009-1016, ISSN 0085-2538

Oberleithner, H.; Kusche-Vihrog, K. \& Schillers H. (2010). Endothelial Cells as Vascular Salt Sensors. Kidney International, Vol.77, No.6, (March 2010), pp 490-494, ISSN 00852538

Perry, RG. \& Pearson, JD. (1989). Endothelium- the Axis of Vascular health and disease. Journal of the Royal College of Physicians, Vol.23, No.2, (April 1989), pp 92-101, ISSN 1478-2715

Pieczenik, SR. \& Neustadt, J. (2007). Mitochondrial Dysfunction and Molecular Pathways of Disease. Experimental and Molecular Pathology, Vol.83, No.1, (August 2007), pp 84-92, ISSN 0531-5522 
Portaluppi, F; Boari, B. \& Manfredini, R. (2004). Oxidative Stress in Essential Hypertension. Current Pharmaceutical Design, Vol.10, No.14, (May 2004), pp 1695-1698, ISSN 13816128

Pupim, L.; Himmelfarb, J.; McMonagle, E.; Shyr, Y. \& Ikizler, T. (2004). Influence of Initiation of Maintenance Hemodialysis on Biomarkers of Inflammation and Oxidative Stress. Kidney International, Vol.65, No.6, (June 2004), pp 2371-2379, ISSN 0085-2538

Rabelink, TJ.; de Boer, HC. \& van Zonneveld, J. (2010). Endothelial Activation and Circulating Markers of Endotelial Activation in Kidney Disease. Nature Reviews Nephrology, Vol.6, No.6, (June 2010), pp 404-414, ISSN 1759-5061

Raggi, P.; Bellasi, A.; Ferramosca, M.; Islam, T.; Muntner, P.; \& Block, GA: (2007). Association of Pulse Wave Velocity with Vascular and Valvular Calcification in Hemodialysis Patients. Kidney International, Vol.71, No.2, (April 2007), pp 802-807, ISSN 0085-2538

Raitakari, OT. \& Celermajer, DS. (2000). Testing for Endothelial Dysfunction. Annals of Medicine, Vol.32, No.5, (July 2000), pp 293-304, ISSN 0003-4819

Ross, R. (1999). Atherosclerosis: an Inflammatory Disease. New England Journal of Medicine, Vol. 340, No.2, (January 1999), pp 115-126, ISSN 0028-4793

Scalera, F.; Kielstein, JT.; Martens-Lobenhoffer, J.; Postel, SC.; Tager, M. \& Bode-Boger, SM. (2005). Erythropoietin Increases Asymmetric Dimethylarginine in Endothelial Cells: Role of Dimethylarginine Dimethylaminohydrolase. Journal of the American Society of Nephrology, Vol.16, No.4; (April 2005), pp 892-898, ISSN 1046-6673

Schnackenberg, CG. (2002). Physiological and Pathophysiological Roles of Oxygen Radicals in the Renal Vasculature. American Journal of Physiology-Regulatory, Integrative and Comparative Physiology, Vol.282, No.2, (February 2002), pp R335-R342, ISSN 03636119

Schwarz, U.; Buzello, M.; Ritz, E.; Stein, G.; Raabe, G.; Wiest, G.; Mall, G. \& Amann, K. (2000). Morphology of Coronary Atherosclerotic Lesions in Patients with End-Stage Renal Failure. Nephrology Dialysis and Transplantation, Vol.15, No.2, (February 2000), pp 218-223, ISSN 0931-0509

Sela, S.; Shurtz-Swirski, R.; Cohen-Mazor, M.; Mazor, R.; Chezar. J.; Shapiro, G.; Hassan, K.; Shkolnik, G; Geron, R. \& Kristal, B. (2005). Primed Peripheral Polymorphonuclear Leukocyte: a Culprit Underlying Chronic Low-Grade Inflammation and Systemic Oxidative Stress in Chronic Kidney Disease. Journal of the American Society of Nephrology, Vol.16, No.8, (August 2005), pp 2431-2438, ISSN 1046-6673

Sigrist, M.; Bungay, P.; Taal, MW. \& McIntyre, CW. (2006). Vascular Calcification and Cardiovascular Function in Chronic Kidney Disease. Nephrology, Dialysis and Transplantation, Vol. 21, No.3, (March 2006), pp 707-714, ISSN 0931-0509

Simonini, A.; Moscucci, M.; Muller, DW.; Bates, ER.; Pagani, FD.; Burdick, MD. \& Strieter RM. (2000). IL-8 is an Angiogenic Factor in Human Coronary Atherectomy Tissue. Circulation, Vol.101, No.13, (April 2000), pp 1519-1526, ISSN 0009-7322

Singh, AK.; Szczech, L.; Tang, KL.; Barnhart, H.; Sapp, S.; Wolfson, M. \& Reddan, D. CHOIR Investigators. (2006). Correction of Anemia with Epoetin Alfa in Chronic Kidney Disease. New England Journal of Medicine, Vol.355, No.20, (November 2006), pp 2085-2098, ISSN 0028-4793 
Stam, F.; van Guldener, C.; Schalkwijk, CG.; ter Wee, PM.; Donker, Ab JM. \& Stehouwer, DA. (2003). Impaired Renal Function is Associated with Markers of Endothelial Dysfunction and Increased Inflammatory Activity. Nephrology Dialysis and Transplantation, Vol.18, No.5, (May 2003), pp 892-898, ISSN 0931-0509

Stenvinkel, P.; Heimbürger, O.; Paultre, F; Ciczfalusy, U.; Wang, T.; Berlglund, L. \& Jogerstrand, T. (1999). Strong Association Between Malnutrition, Inflammation, and Atherosclerosis in Chronic Renal Failure. Kidney International, Vol.55, No.5, (May 1999), pp 1899-1911, ISSN 0085-2538

Stenvinkel, P. (2001a). Malnutrition and Chronic Inflammation as Risk Factors for Cardiovascular Disease in Chronic Renal Failure. Blood Purification, Vol.19, No.2, (February 2001), pp 143-151, ISSN 0253-5068

Stenvinkel, P. (2001b). Endothelial Dysfunction and Inflammation-Is There a Link?. Nephrololoy, Dialysis and Transplantation, Vol.16, No.10, (October 2001), pp 19681971, ISSN 0931-0509

Stenvinkel, P.; Heimbürger, O. \& Lindholm, B. (2004). Wasting, but not Malnutrition, Predicts Cardiovascular Mortality in End-Stage Renal Disease. Nephrology Dialysis and Transplantation, Vol.19, No.9, (September 2004); pp 2181-2183, ISSN 0931-0509

Stenvinkel, P.; Carrero, JJ.; Axelsson, J.; Lindholm, B.; Heimbürger, O. \& Massy Z. (2008). Emerging Biomarkers for Evaluating Cardiovascular Risk in the Chronic Disease Patient: How do New Pieces Fit into the Uremic Puzzle?. Clinical Journal of the American Society of Nephrology, Vol.3; No.2, (March 2008), pp 505-521, ISSN 15559041

Stevens, LA.; Djurdjev, O.; Cardew, S.; Cameron, EC. \& Levin, A. (2004). Calcium, Phosphate, and Parathyroid Hormone Levels in Combination and as a Function of Dialysis Duration Predict Mortality: Evidence for the Complexity of the Association Between Mineral Metabolism and Outcomes. Journal of the American Society of Nephrology, Vol.15, No.3 (March 2004), pp 770-779, ISSN 1046-6673

Tatematsu, S.; Wakino,S.; Kanda, T.; Homma,K.; Yokoshioka, K.; Hasegawa, K.; Sugano, N.; Kimoto, M.; Saruta,T. \& Hayashi,K. (2007). Role of Nitric Oxide-Producing and Degrading Pathways in Coronary Endothelial Dysfunction in Chronic Kidney Disease. Journal of the American Society of Nephrology, Vol.18, No.3, (March 2007), pp 741-749, ISSN 1046-6673

Teitell, M. \& Richardson, B. (2003). DNA Methylation in the Immune System. Clinical Immunology, Vol.109, No.1 (October 2003), pp 2-5, ISSN 0091-6749

Tonelli, M \& Pfeffer, MA. (2007). Kidney Disease and Cardiovascular Risk. Annual Review of Medicine, Vol. 58, No.2, (February 2007), pp 123-139, ISSN 0066-4219

Tong, M.; Carrero, JJ.; Qureshi, AR; Anderstam, B.; Heimbürger, O.; Barany, P; Axelsson, J; Alvestrand, A.; Stenvinkel, P; Lindholm, B. \& Suliman, ME. (2007). Plasma Pentraxin 3 in Chronic Kidney Disease Patients: Associations with Renal Function, Protein-Energy Wasting, Cardiovascular Disease and Mortality. Clinical Journal of the American Society of Nephrology, Vol.2, No.5, (September 2007), pp 889-897, ISSN 1555- 9041

Touyz, RM. (2005). Reactive Oxygen Species as Mediators of Calcium Signaling by Angiotensin II: Implications in Vascular Physiology and Pathophysiology. Antioxidant \& Redox Signaling, Vol. 7, No.9-10, (September-October 2005), pp 13021314, ISSN 1523-0864 
Trimarchi, H; Schiel, A; Freixas, E. \& Díaz M. (2002). Randomized Trial of Methylcobalamin and Folate Effects on Homocysteine in Hemodialysis Patients. Nephron, Vol.91, No. 1, (May 2002), pp 58-63, ISSN 0028-2766

Trimarchi, H.; Mongitore, MR.; Baglioni, P.; Forrester, M.; Freixas, EA.; Schropp, M.; Pereyra, H.; Alonso, M. N-Acetylcysteine Reduces Malondialdehyde Levels in Chronic Hemodialysis Patients--a Pilot Study. (2003). Clinical Nephrology, Vol.59, No.6, (June 2003), pp 441-446, ISSN 0301-0430

Trimarchi, H.; Muryan, A.; Campolo-Girard, V.; Dicugno, M.; Barucca, N.; Lombi, F.; Pomeranz, V.; Forrester, M.; Alonso, M.; Iriarte, R.; Díaz, ML. \& Lindholm, B. (2011). Elevated Pro-Brain Natriuretic Peptide, Troponin T and Malnutrition Inflammatory Score in Chronic Hemodialysis Patients with Overt Cardiovascular Disease. Nephron Clinical Practice, Vol.117; No.3, (March 2011), pp 198-205, ISSN 0028-2766

Valli, A.; Carrero, JJ.; Qureshi, AR.; Garibotto, G.; Barany, P; Axelsson, J; Lindholm, B.; Stenvinkel, P.; Anderstam, B \& Suliman ME. (2008). Elevated Serum Levels of SAdenosylhomocysteine, but not Homocysteine, Are Associated with Cardiovascular Disease in Stage 5 Chronic Kidney Disease Patients. Clinica Chimica Acta, Vol. 395, No.1-2, (September 2008), pp 106-110, ISSN 0009-8981

Van Guldener, C.; Lambert, J.; Janssen, MJFM.; Donker, AJM. \& Stehouwer, CDA. (1997). Endothelium-Dependent Vasodilatation and Distensibility of Large Arteries in Chronic Haemodialysis Patients. Nephrology Dialysis and Transplantation, Vol.12, Suppl.2, (1997), pp 14-18, ISSN 0931- 0509

Vanholder, R.; Hoefliger, N.; De Smet, R. \& Ringoir, S. (1992) Extraction of Protein Bound Ligands from Azotemic Sera: Comparison of 12 Deproteinization Methods. Kidney International, Vol.41, No.4, (June 1992), pp 1707-1712, ISSN 0085-2538

Vanholder, R.; Baurmeister, U.; Brunet, P.; Cohen, G.; Glorieux, G. \& Jankowski, J. for the European Uremic Toxin Work Group. (2008). A Bench to Bedside View of Uremic Toxins. Journal of the American Society of Nephrology, Vol. 19, No.8, (August 2008), pp 863-870, ISSN 1046-6673

Vanhoutte, PM. The Endothelium-Modulator of Vascular Smooth-Muscle Tone. (1988). New England Journal of Medicine, Vol.319, No.8, (August 1988), pp 512-513, ISSN 00284793

Vaziri, ND \& Rodríguez-Iturbe, B. (2006). Mechanisms of Disease: Oxidative Stress and Inflammation in the Pathogenesis of Hypertension. Nature Clinical Practice Nephrology, Vol.2, No.10, (October 2006), pp 582-593, ISSN 1745- 8323

Verma, S. \& Anderson TJ. (2002). Fundamentals of Endothelial Function for the Clinical Cardiologist. Circulation, Vol.105, No.5, (February 2002), pp 546-549, ISSN 00097322

Vita, JA. \& Keaney, JF. (2002). Endothelial Function: A Barometer for Cardiovascular Risk? Circulation, Vol.106, No.6 (August 2002), pp 640-642, ISSN 0009-7322

von Hundelshausen, P. \& Weber, C. (2007). Platelets as Immune Cells: Bridging Inflammation and Cardiovascular Disease. Circulation Research, Vol.100, No.1, (January 2007), pp 27-40, ISSN 0009-7300

Webb, D. \& Vallance, P. (Eds. P. Vallance \& S. Moncada) (1997). Endothelial Function and Hypertension, Springer Verlag, ISBN 9783642158711 Heidelberg 
Weiss, G. \& Goodnough, LT. (2005). Anemia of Chronic Disease. New England Journal of Medicine, Vol.352, No.10, (March 2005), pp 1011-1023, ISSN 0028-4793

Wilcox, CS. (2005). Oxidative Stress and Nitric Oxide Deficiency in the Kidney: a Critical Link to Hypertension? American Journal of Physiology-Regulatory, Integrative and Comparative Physiology, Vol.289, No.4, (October 2005), pp 913-935, ISSN 0363-6119

Yanagisawa, M.; Kurihara, H.; Kimura, S.; Tomobe, Y, Kobayashi, M.; Mitsui, Y; Yazaki, Y; Goto, K. \& Mazaki T. (1988). A Novel Potent Vasoconstrictor Peptide Produced by Vascular Endotelial Cells. Nature, Vol. 332, No.6163, (March 1988), pp 411-415, ISSN 0028-0836

Yilmaz, MI.; Carrero, JJ.; Ortiz, A.; Martín-Ventura, JL.; Sonmez, A.; Saglam, M.; Yaman, H.; Yenicesu, M.; Egido, J. \& Blanco-Colio, LM. (2009). Soluble TWEAK Plasma Levels as a Novel Biomarker of Endothelial Function in Patients with Chronic Kidney Disease. Clinical Journal of the American Society of Nephrology, Vol.4, No.2, (February 2009), pp 1716-1723, ISSN 1555- 9041

Zimmermann , J.; Herrlinger, S.; Pruy, A.; Metzger, T. \& Wanner, C. (1999). Inflammation Enhances Cardiovascular Risk and Mortality in Hemodialysis patients. Kidney International, Vol.55, No.2, (February 1999), pp 648-658, ISSN 0085-2538

Zoccali, C.; Bode-Boger, SM.; Mallamaci, F.; Bendetto, FA.; Trippei, G.; Malatino, L.; Cataliotti, A.; Bellanuova, I.; Fermo, I.; Frölich, JC \& Boger RH. (2001). Plasma Concentrations of Assymetrical Dimethylarginine and Mortality in Patients with End-Stage Renal Disease: A Prospective Study. Lancet, Vol.358, No.9299, (December 2001), pp 2113-2113, ISSN 0140-6736 


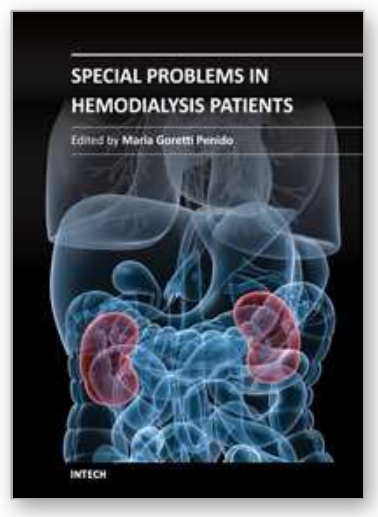

\author{
Special Problems in Hemodialysis Patients \\ Edited by Prof. Maria Goretti Penido
}

ISBN 978-953-307-396-5

Hard cover, 192 pages

Publisher InTech

Published online 14, November, 2011

Published in print edition November, 2011

This book provides an overview of special cases in hemodialysis patients. Authors have contributed their most interesting findings in dealing with patients suffering of other diseases simultaneously, such as diabetes, cardiovascular disease and other health problems. Each chapter has been thoroughly revised and updated so the readers are acquainted with the latest data and observations in these complex cases, where several aspects are to be considered. The book is comprehensive and not limited to a partial discussion of hemodialysis. To accomplish this we are pleased to have been able to summarize state of the art knowledge in each chapter of the book.

\title{
How to reference
}

In order to correctly reference this scholarly work, feel free to copy and paste the following:

Hernán Trimarchi (2011). The Endothelium and Hemodialysis, Special Problems in Hemodialysis Patients, Prof. Maria Goretti Penido (Ed.), ISBN: 978-953-307-396-5, InTech, Available from:

http://www.intechopen.com/books/special-problems-in-hemodialysis-patients/the-endothelium-andhemodialysis

\section{INTECH}

open science | open minds

\section{InTech Europe}

University Campus STeP Ri

Slavka Krautzeka 83/A

51000 Rijeka, Croatia

Phone: +385 (51) 770447

Fax: +385 (51) 686166

www.intechopen.com

\section{InTech China}

Unit 405, Office Block, Hotel Equatorial Shanghai

No.65, Yan An Road (West), Shanghai, 200040, China

中国上海市延安西路65号上海国际贵都大饭店办公楼405单元

Phone: +86-21-62489820

Fax: +86-21-62489821 
(C) 2011 The Author(s). Licensee IntechOpen. This is an open access article distributed under the terms of the Creative Commons Attribution 3.0 License, which permits unrestricted use, distribution, and reproduction in any medium, provided the original work is properly cited. 